\title{
Construction of Social Sustainability in Milk Production Systems in Central Mexico
}

\author{
Ruiz-Torres M.E. ${ }^{1}$, Lorga da Silva A. ${ }^{2}$, Arriaga-Jordán C.M. ${ }^{1}$ y Martínez-Castañeda F.E. ${ }^{{ }^{*}}$
}

1 Universidad Autónoma del Estado de México. Instituto de Ciencias Agropecuarias y Rurales (ICAR). Instituto Literario \#100, Col. Centro, 50000. Toluca, Estado de México, México. 2 Universidade Lusófona de Humanidades e Tecnologias. Departamento de economía e Gestão. Campo Grande, 376, 1749-024. Lisboa, Portugal.

*Corresponding Author: femartinezc(auaemex.mx

\begin{abstract}
Objective: To build mathematical models to evaluate the social sustainability of small-scale milk production systems.

Design/Methodology/Approach: Thirty small-scale cowsheds were analyzed. Two models were built using multivariate regression, estimated with ordinary least squares and considering the factors that producers perceive as important for social sustainability.
\end{abstract}

Results: The first model (ER) included tangible variables and the second intangible variables (SR). Both models explained more than $80 \%$ of the variables associated with social sustainability.

Study Limitations/Implications: The results represent an effort to link the statistical analysis with qualitative data that is difficult to quantify.

Conclusions: The ER and SR models represent a proposal for counting immaterial indicators so they can be incorporated into the sustainability analysis. Both models could be a methodological proposal to connect statistical data with purely qualitative data such as perception.

Keywords: Livestock production, mathematical models, ethnography, social structures.

\section{INTRODUCTION}

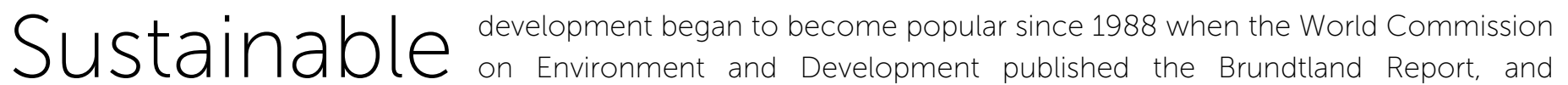
sustainability was defined as that which can satisfy the needs of the present generation without compromising the ability of future generations to satisfy their own needs (WCED, 1987). This definition has been taken up again frequently in the studies of resource use and environmental problems, and although it involves the economic and social spheres, these are only relevant if they are compatible with the environmental quandary (Janker et al., 2019).

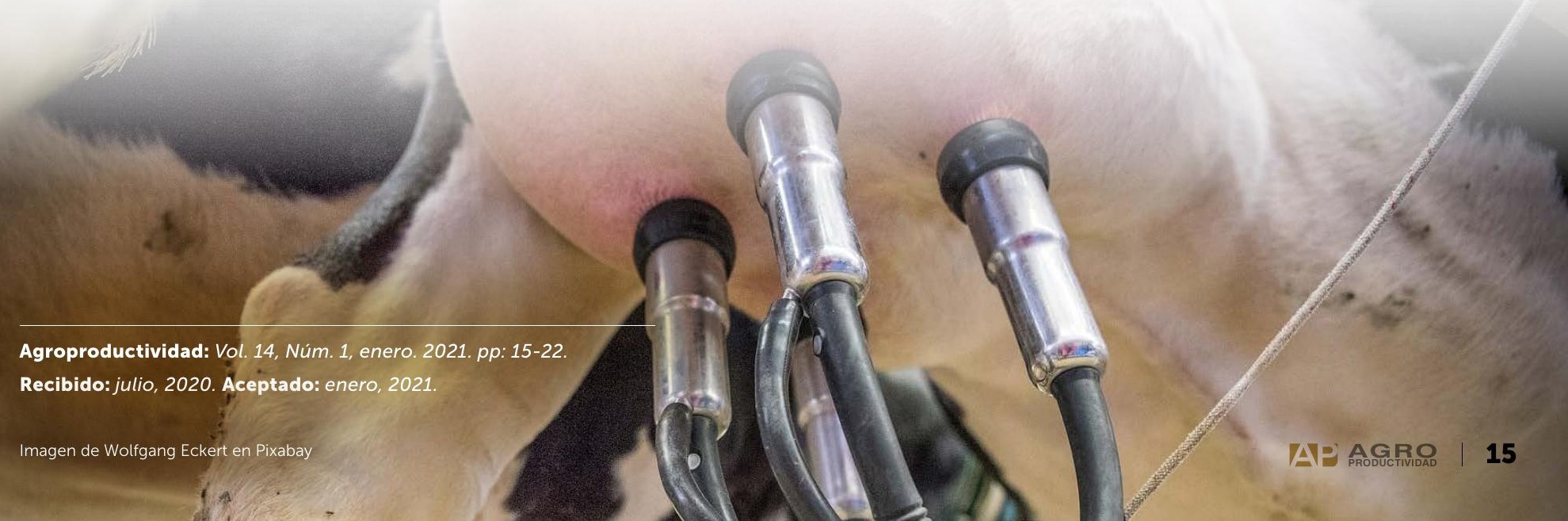


During the first years of the 21st century, studies such as Pretty's (2000) began to analyze certain productive activities under the notions of sustainability, giving rise to a series of studies on sustainable agriculture (Maxey, 2006; Graymore et al., 2008) and livestock production (Bigras-Poulin et al., 2004; Rojas-Downing et al., 2017).

Sustainability in its social conceptualization has been described as a multifunctional concept (De Wit et al., 1995) and has been analyzed from diverse perspectives. From the agricultural point of view, Janker et al. (2019) propose the analysis of the social dimension of sustainability through a working framework that contemplates the identification of local elements of the agricultural system. Saifi and Drake (2008), for their part, consider that sustainable agriculture is constructed by thinking about municipalities as socio ecological systems capable of reducing the national and global interconnection regarding the main agricultural inputs. Veldhuizen et al. (2015) consider that the studies on social sustainability ought to consult different groups of the parties interested in order to obtain a balanced view about the problems of productive systems.

Due to the multi-functionality of the concept of social structures, there has been scarce consensus about what social sustainability is and ought to include, particularly for rural studies; however, authors such as Karami and Mansoorabadi (2008), Vallance et al. (2011), and Dlouhá et al. (2013), have preferred to root social sustainability through the categories of tangible needs (water, food, shelter) and intangible needs (culture, human values, social networks, equity and justice). Authors like Janker et al. (2019) propose that for the empirical application of the social sustainability framework in rural areas (sustainable agricultural systems) it is required to identify local elements of the productive system and for actors to identify their needs with regards to the system and their working conditions.

Despite the efforts to build evaluation tools for social sustainability, there are still no pre-established social criteria used as variables, so that at the methodological level the concept continues to be vague (Olakitan, 2019). This study attempts to contribute to decrease this methodological gap and combines ethnographic and statistical approaches for the determination of variables defined by the social actors involved, which are necessary for the satisfaction of tangible and intangible needs. Milk production systems, both in Mexico and in other global economies, have been positioned within the five agro-productive systems of greatest importance (FAO, 2016). However, attaining productive increments constitutes a challenge, since the dairy farms have constantly had to face changes in economic and technical scenarios, causing their profitability to be affected (Calsamiglia et al., 2018). Based on this, the objective of this study was to develop mathematical models to evaluate social sustainability in small-scale milk production systems in Central Mexico.

\section{MATERIALS AND METHODS}

The research was carried out in two localities of the municipality of Aculco, Estado de México, Mexico, with great reputation as milk producer given that it produces close to $3 \%$ of the state total, that is, more than 17 thousand tons of milk (SEDAGRO, 2013).

The localities selected were: El Tixhiñú $\left(99^{\circ} 52^{\prime} 31^{\prime \prime} \mathrm{W}\right.$ and $20^{\circ} 06^{\prime}$ $\left.54^{\prime \prime} \mathrm{N}\right)$, with altitude of $2,438 \mathrm{~m}$, and La Concepción Ejido (99 52' 23" $W$ and $20^{\circ} 07^{\prime} 59^{\prime \prime} N$ ) with altitude of $2,399 \mathrm{~m}$. Both localities are considered in the cultural imaginary of the zone as the most important in terms of milk production.

\section{Sample of Producers}

The study was done with $n=30$ productive units, 17 in Tixhinú and 13 in Concepción Ejido. The sample represented $14.70 \%$ of the total production units present in the study zone and in agreement with Palella and Martins (2012), a sample of 10 , 20 or $40 \%$ can be representative and valid as long as the characteristics of the study subjects are universal for the population. These production units were selected through a snowball non-probabilistic sample. Selection criteria for the sample were specified (Otzen and Manterola, 2017), among which the following stand out: a) small-scale production, that is, size of the herd between two and thirty milking cow plus replacements; b) milk production was their main source of income, although it was possible for some member of the family to have a paid job; c) the main feeding input of the livestock are local fodders, and d) predominately make use of family workforce. Work was also carried out with key informants, a municipal delegate from each locality, an ejido commissioner and a canal worker in charge of both localities.

The data were collected through ethnographies carried out within the productive units (PUs) and 
qualitative field work techniques, especially in-depth interviews with each member of the PUs in the sample. These interviews were led as informal conversations, so that the interviewee could respond without pressure and spontaneously (Espinoza-Guzmán et al., 2018).

The interview was divided into two stages: a) the first was focused on obtaining general information about the PU and sociodemographic characteristics of the producers; and b) the second stage sought to obtain the perception of the producers about what it implied to be a milk producer and how to achieve sustainable productive systems, that is, they were asked about the elements that they considered part of the economic (tangible) and social (intangible) structures of production. The field work period was from January 2014 to July 2015. In order to have correspondence with the objective of the study, only the general results of the characteristics of the PUs are presented, and the models' results are presented in their developed form.

\section{Building Mathematical Models}

According to Karami and Mansoorabadi (2008), social sustainability should be measured in terms of satisfaction of basic needs, which for Vallance et al. (2011) are classified into tangible (employment, income, infrastructure) and intangible (culture, social networks, generational transference). Following these proposals and with the aim of being able to quantify the factors which, from the perception of producers, have influence on social sustainability of small-scale milk production, two models were built from multiple regression, estimated with the ordinary least squares method (OLS) (Wooldrige, 2015).

It should be mentioned that all the indicators in the models were selected according to recommendations by Janker et al. (2019), through the identification of local elements of the productive system.

The first model, ER, analyzed the perceptions that producers associate with the economic structures that intervene in milk production, that is, the tangible aspects of production. Meanwhile, the second model, SR, was focused on the social structures, that is, the intangible aspects such as traditional knowledge and social networks. The equations applied were:

$$
E R_{i}=\beta_{0}+\beta_{j} \mathrm{X}_{j i}+\varepsilon_{i}, \quad j>1, \quad i=1, \ldots, 30
$$

(1.1) $1<=j<=5$

$$
S R_{i}=\beta_{0}+\beta_{j} \mathrm{X}_{j i}+D_{1 i}+\varepsilon_{i}, \quad j>1, \quad i=1, \ldots, 30
$$

(1.2) $j=3$

$D_{1 i}$ is a dummy variable, $\varepsilon_{i}$ represents the error.

For the construction of the response variable in both models, the PUs were asked for the indicators that they considered an essential part for the satisfaction of tangible (ER) and intangible (SR) needs.

ER was built considering the total number of hectares with cultivated pastures, total of hectares sown with maize, and total number of milking cows.

On the other hand, SR was built considering the average of the following variables: number of people with whom irrigation water is shared, number of people from the family who work in the farm, number of permanent employees, and number of temporal workers. All of these were recorded in the same metric measurement unit.

It is important to emphasize that the variables shown in Table 1, which fed both models, were selected through the declarations from producers about what they perceive as tangible and intangible aspects of social sustainability (Janker et al., 2019). Thus, for the purpose of this study, social sustainability was defined in terms of the categories of needs, tangible for ER and intangible for SR. All the variables were considered numerical in the same way that Wooldridge (2011) considers the years of education and the experience to explain the average of profit per hour.

Finally, for both models, ER and SR, two results were obtained. The first belongs to the complete model, that is, it includes all the variables that are directly related, based on the perception of producers, while the second only includes the variables that were statistically significant. The software used for the analyses was IBM SPSS Statistics version 20 and Gretl Statistics (Gnu Regression, Econometrics and Time-series Library).

\section{RESULTS AND DISCUSSION}

\section{General Characteristics of the Production Units}

The productive units (PUs) have on average four members of the family, of which at least two work daily in milk production, the mean age of the producers is 53 years, with average schooling of finished primary 


\begin{tabular}{|c|c|}
\hline Variable & Definition \\
\hline DC & Total milking cows \\
\hline CP & Total of hectares \\
\hline MA & Total of maize hectares \\
\hline SW & Total number of people whom the producer organizes to pay the water quota \\
\hline MWF & Total family members that contribute to productive activities \\
\hline NPE & $\begin{array}{l}\text { Total number of permanent employees, who are hired when family labor is not available, work directly } \\
\text { with the animal herd, do not have a contract termination date and their salary is received per week }\end{array}$ \\
\hline NTP & $\begin{array}{l}\text { Employees hired for short periods of time, can be days, weeks and / or specific jobs on agricultural land; } \\
\text { their salary is received daily or, at harvest time, they usually receive their income per bag of harvested corn }\end{array}$ \\
\hline PLM & Price of a liter of milk (\$USD)* \\
\hline SJ & Total of family members with a salary out or in the study area \\
\hline AGE & Producer age at the moment of the interview \\
\hline $\mathrm{TL}$ & Total of milk yield at the moment of the interview \\
\hline CA & Milking calves (0 to 6 month of age) \\
\hline IFS & Farm technology** \\
\hline TBA & Total of backyard animals \\
\hline DR & Refers to farms which had social relations outside the study area via salary jobs*** \\
\hline \multicolumn{2}{|c|}{$\begin{array}{l}\text { ** Types of facilities: 1) farms that do not have a defined space for the livestock; 2) farms that only have a space called } \\
\text { cowshed, used as dormitory and trough of milking cows; 3) farms that have a cowshed with pen in a totally demarcated } \\
\text { single space; and 4) those farms that have cowshed and pen that are completely separate, where the pen is the demarcated } \\
\text { place for the livestock to wander during most of the day. }\end{array}$} \\
\hline
\end{tabular}

(six years of elementary school). There are no speakers of indigenous languages in the study zone and the predominant religion is Catholic. The dairy herd has on average 11 milking cows with a production of $170 \mathrm{~L}$ of milk per day. Two milking events are carried out per day and in $90 \%$ of the cases it is done manually. Concerning the backyard animals, there are on average five sheep, six rabbits, one pig and 27 fowl for each PU.

On average, 1.6 ha is destined for the cultivation of pastures, and 4.0 ha for the cultivation of maize and other local fodders, particularly oats. It should be mentioned that the PU with greatest land ownership has an ejido property regime. There is qualified hired labor inside the PUs analyzed, and on average two temporal employees are hired for the sowing and harvesting times. In the study zones there are both property in Tixhiñú and ejido in La Concepción.

\section{Model for the Analysis of Tangible Economic Structures (ER)}

Table 2 presents the two results from the analysis developed for the model of the economic or tangible structures of social sustainability in the PUs registered; that is, ER1 corresponds to the analysis with the totality of the variables expressed by producers and ER2 expresses only the statistically significant variables. It should be mentioned that when comparing ER1 and ER2, the variation percentage of the response variable (ER) was very similar, so these models explain $54 \%$ of the rate of variables which, in the perception of small-scale milk producers, represent the necessary economic aspects for the satisfaction of tangible needs and thus achieve for dairy farms to be sustainable.

The MWF and NPE variables were the ones of greatest significance, followed by PLM. The high significance of variable MWF agrees with the observations by García et al. (2003), who suggest that the farms with smaller herds and which depend 100\% of family labor have higher competitiveness of the system in comparison with the larger farms that are not so dependent on family labor. For Posadas-Domínguez et al. (2014), family labor provides profitability and competitiveness to small-scale milk production, and represents a source of social capital. In addition, it has an impact on the direct production costs and the increase of income (Cabrera et al., 2010; Zhou et al., 2013). 


\begin{tabular}{|c|c|c|c|}
\hline Variable & $R^{2}$ & Standard coefficient & Standard error \\
\hline ER1 & 0,55 & & \\
\hline Constant & & $-0,357^{\star}$ & 0,205 \\
\hline MWF & & $0,010 * * \star$ & 0,003 \\
\hline PLM & & $0,989 *$ & 0,576 \\
\hline NPE & & $0,014^{\star \star \star}$ & 0,004 \\
\hline SJ & & $-0,002$ & 0,003 \\
\hline NTE & & 0,001 & 0,002 \\
\hline ER2 & 0,54 & & \\
\hline Constant & & $-0,357^{\star}$ & 0,199 \\
\hline MWF & & $0,011^{* * *}$ & 0,003 \\
\hline PLM & & $0,988^{*}$ & 0,558 \\
\hline NPE & & $0,012^{* * *}$ & 0,003 \\
\hline
\end{tabular}

${ }^{* * *} p<0.01,{ }^{* *} p<0.05,{ }^{*} p<0.1$

With regards to the variable PLM, it would be logical to think that milk sales are carried out seeking the highest price; however, ethnographic data indicated that there are social factors that have influence on the decisions about who to sell to.

In the study zone, all producers deliver their milk to boteros or stockpiling agents, who transform it into cheese, so the price is established by them. It was observed that the bonds of trust, friendship and camaraderie influence directly on the decisions of who to sell the product to and the PUs do not necessarily seek a better price, which agrees with Oddone (2012) who shows that friendship and camaraderie networks are a cultural and symbolic practice that allows the individual to maintain or improve his level of material, physical and emotional wellbeing through various practices.

Through the ER model, it was detected that, as mentioned by Rao and Qaim (2013), hiring agricultural employees has a positive effect on rural zones. According to Dupraz and Latruffe (2015), family and hired labor can be substituted one with the other, as long as it is about the technical operations of the farm; however, these hires can be affected directly by the changes of nonagricultural salaries (Yang-Ming et al., 2012), reason why the NTE variable was not significant, since there is not an exact programming or control of the paid laborers per day or per harvest.

Contrary to what was established by Meert et al. (2005), for whom paid work constitutes a strategy for the survival of farms, the SJ variable was not statistically significant; however, the ethnographic data confirm that the income obtained outside the farm contributes to stabilizing the finances of households that would otherwise be strongly influenced by the fluctuations of prices and seasonal cycles, which belong to the business cycles of agricultural and livestock products.

\section{Model for the Analysis of Intangible Social Structures (SR)}

Table 3 presents the results from the SR Model. The immaterial structures are difficult to count because they depend directly on the limits established by social actors on environments and interests perceived individually (Stewart et al., 2010); this explains the variability in the data. However, these immaterial components, such as social networks, are critical components for the safety and wellbeing of households, especially in rural zones (Baird and Gray, 2014).

The power relations and social hierarchy represented by the IFS variable were positive and significant both statistically and ethnographically, since as is shown in the testimonies, the producers constantly seek to improve the facilities of the PU, which agrees with what is suggested by Jacoby and Mansuri (2015) who express that the social hierarchy exerts a deep effect on the accumulation of capital in rural zones.

The positive coefficient associated to the DR variable represented a strategy of family PUs to build a complex

\begin{tabular}{|c|c|c|c|}
\hline Variable & $R^{2}$ & Standard coefficient & Standard error \\
\hline SR1 & 0,37 & & \\
\hline Constant & & $8,571^{* *}$ & 3,237 \\
\hline AGE & & $-0,091^{*}$ & 0,049 \\
\hline $\mathrm{TL}$ & & $-0,014^{\star *}$ & 0,006 \\
\hline CA & & $-0,408^{*}$ & 0,226 \\
\hline IFS & & $1,482^{*}$ & 0,738 \\
\hline DR & & $2,508^{*}$ & 1,334 \\
\hline TBA & & 0,004 & 0,018 \\
\hline SR2 & 0,36 & & \\
\hline Constant & & $8,669 * *$ & 3,148 \\
\hline AGE & & $-0,090^{\star}$ & 0,049 \\
\hline $\mathrm{TL}$ & & $-0,014^{\star \star}$ & 0,006 \\
\hline CA & & $-0,391^{*}$ & 0,210 \\
\hline IFS & & $1,466^{*}$ & 0,720 \\
\hline DR & & $2,528^{*}$ & 1,305 \\
\hline
\end{tabular}

${ }^{* * *} p<0.01,{ }^{* *} p<0.05,{ }^{*} p<0.1$ 
social network that allowed sustaining unforeseen agricultural and family events through work loans, savings plans, group savings schemes (informal financial strategy that can be weekly, biweekly or monthly), among others. Authors like Verswijvel et al. (2018) mention that friendship networks depend on trust and can provide the opportunity to expand social circles and create social capital.

The variable associated to age (AGE) had a negative influence on the SR model, because when ageing, the social interactions of the producer decrease given that they no longer have to widen their network since the farm is consolidated, although it is also because the phenomenon of generational transition (material and immaterial) takes place as the producer ages. The socio-productive relationships that were part of an extensive social interweaving begin to change, and the trust that there was in each of the parts of the former network is not transferred in its totality, losing nodes of social relationships, and forcing the new successor to add new actors to the network. It should be mentioned that when the transition is made, the father only conserves the symbolic ownership of the cowshed so that although the son becomes the administrator, he only receives total social recognition after the father's death.

The CA variable had a negative influence on the SR model because, according to field data, the milk production systems sell only male calves and keep the females as replacements for the dairy herd. Considering that the birth rate between sexes is $50 / 50 \%$, the producers only create social relationships for half the births.

It is important to mention that for the TBA variable, based on the perception of small-scale milk producers, it is necessary for the creation of camaraderie and friendship networks that allow exchanges through reciprocity, so this contributes to the social sustainability of the system; however, in the statistical analysis its coefficient was not significant. The reason for this was that people only share a small number of backyard animals and on special occasions the rest is used for auto-consumption of the domestic group whether in feeding or in programmed and extraordinary economic expenses, as Stroebel et al. (2011) describe. For Kariuki et al. (2013), backyard livestock production plays an important role for the families since the animals and the products can be exchanged or sold to purchase food, especially in times of scarcity, in addition to being a conservation space for agrobiodiversity (Rodríguez and Meza, 2014).

According to Vargas-Hernández (2010), the creation of social capital is one of the greatest foundations of sustainability since because it's based on elements of trust and reciprocity, coordinated actions can be eased in favor of environmental protection; therefore, it is suggested to place special emphasis on the variables related to the SR model, which can generate links between producers to act as platforms for plans and programs in favor of the region's sustainable development.

\section{CONCLUSIONS}

The hybrid methodologies used allowed contributing evidence where the inclusion of traditional knowledge and social participation have not been incorporated into sustainability analyses, because the indicators of these variables are located in the immaterial context and the socio-cultural category. Likewise, the ER and SR models fulfill the purpose of counting these immaterial indicators to be able to incorporate them into the sustainability analyses, so they constitute a methodological proposal that combines ethnographic data and statistical analyses. ER and SR together explain slightly over $80 \%$ of the variance rate of the variables considered for the evaluation of sustainability in smallscale milk production systems. For the case of the category that included the satisfaction of tangible needs (ER), the variables with highest influence are price of a liter of milk, number of permanent employees, and members of the family that work in the farm. In the case of the category of satisfaction of intangible needs (SR), the variables that contribute most to the model due to their significance are domestic roles and infrastructure. The methodological proposal developed in this study represents an effort to connect the statistical analyses with purely qualitative data and difficult to materialize, such as perceptions.

\section{AKNOWLEDGEMENTS}

We thank the producers in the study zone for their complete willingness and collaboration with the working team. This study is part of the project with key 129449/2009 financed by CONACyT

\section{REFERENCES}

Baird, T. y Gray, C. (2014). Livelihood Diversification and Shifting Social Networks of Exchange: A social network transition?. World Development, 60,14-30.

Bigras-Poulin, M., Ravel, A., Bélanger, D. y Michel, P. (2004). Development of agroenvironmental indicators to evaluate the hygienic 
pressure of livestock production of human health. International Journal of Hygiene and Environmental Health, 207, 279-295.

Cabrera, V., Solís, D. y del Corral, J. (2010). Determinants of technical efficiency among dairy farms in Wisconsin. Journal of Dairy Science, 93, 387-393.

Calsamiglia, S., Astiz, S., Baucells, J. y Castillejos, L. (2018). A stochastic dynamic model of a dairy farm to evaluate technical and economic performance under different scenarios. Journal of Dairy Science, 101,8, 7517-7530.

De Wit, J., Oldenbroek, J.K., Van Keulen, H. y Zwart, D. (1995) Criteria for sustainable livestock production: a proposal for implementation. Agriculture, Ecosis y Environ, 53, 219-229.

Dlouhá, J., Barton, A., Janousková, S. y Dlouhy, J. (2013). Social learning indicators in sustainability- oriented regional learning networks. Journal of Cleaner Production, 49, 64-73.

Dupraz, P. y Latruffe, L. (2015). Trends in family labour, hired labour and contract work on French field crop farms: The Role of the Common Agricultural Policy. Food Policy, 51, 104-118.

Espinoza-Guzmán, M.A., Pineda-López, M.R., Sánchez-Velásquez, L.R., Ruíz-Gómez, M.G. y López-Espejel, Z.I. (2018). La sustentabilidad en tres empresas sociales de la region de los Tuxtla, Veracruz, México. Sociedad y Ambiente, 7,18, 231-254.

FAO (2016). El sector lechero mundial: Datos. Food and Agriculture Organization of the United Nations. http:// www. dairydeclaration.org/Portals/153/FAO-Global-FactsSPANISH-F.PDF?V $=1$

García, O., Mahmood, K. y Hemme, T. (2003). A review of milk production in Pakistan with particular emphasis on small-scale producers. PPLPI Working Paper. www.fao.org/ag/againfo/ programmes/en/pplpi/docarc/wp3.pdf

Graymore, M., Sipe, N. y Rickson, R. (2008). Regional sustainability: How useful are current tools of sustainability assessment at the regional scale. Ecological Economics, 67, 362-372.

Jacoby, H. y Mansuri, G. (2015). Crossing boundaries: How social hierarchy impedes economic mobility. Journal of Economic Behaviour and Organization, 117, 135-154.

Janker, J., Mann, S. y Rist, S. (2019). Social sustainability in agriculture- A system-based framework. Journal of Rural Studies, 65, 32-42.

Karami, E. y Mansoorabadi, A. (2008). Sustainable agricultural attitudes and behaviours: a gender analysis of Iranian farmers. Environment Development and Sustainability, 10,6, 883-898.

Kariuki, J., Njuki, J., Mburu, S. y Waithanji, E. (2013). Women, Livestock Ownership and food security. In Jemimah, N., Pascal, S. (editors), Women, Livestock Ownership and Markets. Bridging the gender gap in Eastern and Southern Africa, USA: RoutledgeTaylors and Francis Group. 95-110.

Maxey, L. (2006). Can we sustainable agriculture? Learning from small-scale producer-suppliers in Canada and the UK. The Geographical Journal. 172(3), 230-244.

Meert, H., VanHuylenbroeck, G., Vernimmen, T., Bourgeois, M.yVanHecke, É. (2005). Farm household survival strategies and diversification on marginal farms. Journal of Rural Studies, 21, 81-97.

Oddone, M.J. (2012). Estrategias de supervivencia, vida cotidiana e impacto de las redes de apoyo social para los trabajadores de mayor edad desocupados. Revista del Centro de Investigación de la Universidad la Salle, 10,38, 117-139.

Olakitan, A.J. (2019). Developing a social sustainability assessment framework. Sustainable Cities and Society, 44, 237-252.
Otzen, T.yManterola, C. (2017).Técnicas demuestreosobreunapoblación de estudio. International Journal of Morphology, 35, 227-232.

Palella, S.S. y Martins P.F. (2012). Metodología de la Investigación Cuantitativa. 3a edición, Venezuela: Ed. FEDUPEL. 285 pp.

Posadas-Dominguez, R.R., Arriaga-Jordán, C.M. y Martínez-Castañeda, F.E. (2014). Contribution of family labour to the profitability and competitiviness of small scale dairy production systems in central Mexico. Tropical Animal Health and Production, 46, 235-240

Pretty, J. (2000). Can sustainable agriculture feed Africa? New evidence in progres, proccesses and impacts. Environment Development and Sustainability. 1, 253-274.

Rao, E. y Qaim, M. (2013). Supermarkets and agricultural labor demand in Kenya: A gendered perspective. Food Polocy, 38, 165-176.

Rodríguez, A. y Meza, L. (2014). Agrobiodiversidad, agricultura familiar y cambio climático. Santiago de Chile: CEPAL-Naciones Unidas. $92 \mathrm{pp}$.

Rogerio, M.M., Sandin, R.R., Campos, P.D.S., Alves, C.M., Murgueittio, E., Chará, J. y Flores E.M.X. (2018). Silvopastoral Systems in Latin America for Biodiversity, Environmental, and Socioeconomic Improvements. Agroecosystem Diversity. In Gilles Lemaire, $P$. et al.(editores). Reconciling Contemporary Agriculture and Environmental Quality. USA: Academic Press. 287-297

Rojas-Downing, M., Nejadhashemi, P., Harrigan, T. y Woznicki, S. (2017). Climate change and livestock: Impacts, adaptation and mitigation. Climate Risk Management, 16, 145-163.

Ruiz Meza, L.E. (2014). Género y percepciones sociales del riesgo y la variabilidad climática en la region del Soconusco, Chiapas. Alteridades, 24,47, 77-88.

Saifi, B. y Drake, L. (2008). A coevolutionary model for promoting agricultural sustainability. Ecological Economics, 65, 24-34.

Schönborn, G., Berlin, C., Pinzone, M., Hanisch, C., Georgoulia, K. y Lanz, M. (2019). Why social sustainability counts: The impact of corporate social sustainability culture on financial success. Sustainable Production and Consumption, 17, 1-10

SEDAGRO. (2013). Producción Agropecuaria por Municipio 2013. Secretaria de Desarrollo Agropecuario-Estado de México. http://sedagro.edomex.gob.mx/produccion_floricola

Stewart, R., Bechhofer, F., McCrone, D. y Kiely, R. (2010). Keepers of the land: Ideology and identities in the Scottish rural elite. Identitie, 8,3, 381-409.

Stroebel, A., Swanepoel, F. y Pell, A. (2011). Sustainable smallholder livestock systems: A case study of Limpopo Province, South Africa. Livestock Science, 139, 186-190.

Vallance, S., Perkins, H. y Dixon, J. (2011). What is social sustainability? A clarification of concepts. Geoforum, 42, 342-348.

Vargas-Hernández, J. (2010). Capital social y organizacional base de la sustentabilidad organizacional para el desarrollo ambiental y económico: El caso de las micro y pequeñas empresas en la explotación del Tule (Typha spp.) de la Laguna de Zapotlane. Panorama Socioeconómico, 28,41, 160-177.

Veldhuizen, L., Berentsen, P. Bokkers, E.A.M. y de Boer, I. (2015). A method to assess social sustainability of capture fisheries: An application to a Norwegian trawler. Environmental Impact Assessement Review, 53, 31-39.

Verswijvel, K., Heirman, W., Hardies, K. y Walrave, M. (2018). Designing and validating the friendship quality on social network sites questionnaire. Computers in Human Behavior, 86, 286-298. 
WCED. World Commision on Environment and Development. (1987) "Our common future" UK: Oxford University Press. 300 pp.

Wooldridge, J. (2015). Introductory Econometrics: A modern approach. 5th Edition, USA: Cenage Learning Editions. 910 pp.

Yang-Ming, C., Biing-Wen, H. y Yun-Ju, C. (2012). Labor supply, income, and welfare of the farm household. Labour Economics, 19,3, 427-47.

Zhou, S., Huang, Y., Yao, C., Runhang, L. y Liu, X. (2013). Labor cost analysis for pome production in different cultivation modes in Hebei Province. Asian Agricuture Research. 5(4), 36-40.

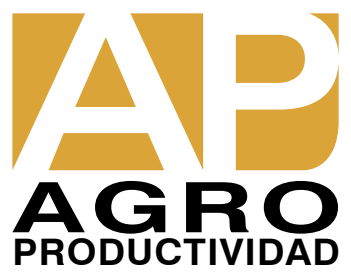

22 | IAVP A AGRO 